\title{
FENOMENA SOSIAL PERNIKAHAN DINI DI DESA PACE KECAMATAN SILO KABUPATEN JEMBER
}

\author{
Nadiratul Laeli \\ Program Studi Bimbingan Konseling Islam, UIN Kiai Haji Achmad Siddiq Jember \\ nadiratullayli@gmail.com \\ Muhammad Suwignyo Prayogo \\ UIN Kiai Haji Achmad Siddiq Jember \\ wignyoprayogo86@gmail.com
}

\begin{abstract}
Abstrak
Pernikahan dini merupakan suatu hal yang masih dianggap wajar, bahkan di Indonesia pernikahan dini telah menjadi fenomena sosial budaya yang memiliki pengaruh besar dalam kehidupan masyarakat Indonesia. Beberapa desa di Indonesia masih memberikan respon positif terhadap pernikahan dini. Padahal kita semua tahu bahwa banyak akibat negatif dari pernikahan dini. Oleh karena itu, penelitian ini bertujuan untuk mengkaji penyebab dan dampak yang terjadi akibat pernikahan dini, agar masyarakat dapat sadar dan berubah pikiran yang menganggap bahwa pernikahan dini adalah hal yang wajar untuk dilakukan. Metode penyelesaian yang digunakan untuk mengatasi fenomena tersebut adalah dengan menggunakan metode pendidikan masyarakat. Faktor penyebab pernikahan dini adalah faktor diri sendiri, dimana karena mereka sudah saling mengenal dan mencintai akhirnya mereka sepakat untuk melanjutkan hubungan kejenjang pernikahan dan juga disebabkan faktor lingkungan yang masih menganggap pernikahan dini sebagai hal biasa. Serta berdampak pada putusnya sekolah, perceraian rumah tangga dan terjadinya kekerasan rumah tangga.
\end{abstract}

Kata Kunci: Fenomena Sosial, Pernikahan Dini, Desa Pace

\section{Abstrac}

Early marriage is something that is still considered normal, even in Indonesia, early marriage has become a socio-cultural phenomenon that has a major influence on the lives of Indonesian people. Several villages in Indonesia still give a positive response to early marriage. Yet we all know that there are many negative consequences of early marriage. Therefore, this study aims to examine the causes and impacts that occur due to early marriage, so that people can be aware and change their minds who think that early marriage is a natural thing to do. The settlement method used to overcome this phenomenon is to use the community education method. The factor that causes early marriage is the self factor, where because they already know and love each other they finally agree to continue the relationship at the marriage level and also due to environmental factors which still consider early marriage as normal. As 


\section{Nadiratul Laeli dan Muhammad Suwignyo Prayogo}

well as having an impact on dropping out of school, household divorce and the occurrence of domestic violence.

Keywords: Social Phenomenon, Early Age Marriage, Pace Village

\section{Pendahuluan}

Setiap makhluk hidup diciptakan berpasang-pasangan, yang kemudian mereka mengiikat suatu hubungan dengan melaksanakan suatu pernikahan dengan harapan dapat membentuk keluarga sakinah mawaddah warohmah. Pernikahan merupakan upacara untuk mengikat janji nikah yang di sepakatu dan dilaksanakan oleh dua orang, agar ikatan pernikahan resmi secara norma agama, norma sosial dan norma hukum. Penggunaan adat atau aturan tertentu dalam pernikahan seringkali berkaitan dengan hukum agama atau aturan tertentu yang berlaku dalam suatu masyarakat atau kelompok, jadi tidak heran jika upacara pernikahan memiliki bannyak ragam dan variasi yang digolongkan menurut tradisi suku agama, bangsa, budaya, maupun kelas sosial.

Keluarga dibentuk untuk memadukan kasih sayang antara laki-laki dan perempuan untuk memperoleh kebahagiaan serta kesejahteraan hidup. Mereka kemudian menyebarkan sifat keayahan dan keibuan terhadap seluruh anggota keluarganya agar tercapai keinginan mereka untuk hidup sejahtera dan bahagia. Pasangan yang akan membentuk keluarga harus mempersiapkan dengan sangat matang, mereka harus bertanggung jawab dan sudah dewasa secara biologis atau perdagogis. seorang laki-laki harus sudah siap mengemban tanggung jawabnya sebagai pemimpin atau kepala keluarga yang berkewajiban mencukupi nafkah anggota keluarganya, seorang wanita harus sudah siap mengemban dan melaksanakan kewajibannya menjadi ibu rumah tangga sebaga pengendali rumah tangga, mendidik, melahirkan serta mengasuh-anak-anaknya

Selain itu dalam pernikahan juga kerap sekali terjadi pernikahan pada usia muda, sehingga karena mereka belum siap menghadapi masalah dalam keluarga maka memberikan banyak dampak negatif dalam hubungan mereka, dalam hal ini dikenal dengan istilah pernikahan dini. Adapun pernikahan dini adalah pernikahan yang dilakukan oleh pasangan yang mana salah satu atau kedua pasangan usianya di bawah 18 tahun, jadi ketika pria maupun wanita yang belum cukup umur melangsungkan pernikahan maka pernikahannya dapat di sebut pernikahan dini ${ }^{1}$

1 Yanti DKK, "Analisis Faktor Penyebab dan Dampak Pernikahan Dini di Kecamatan Kandes Kabupaten Siak", Jurnal Ibu dan Anak Vol 6 No 2 (2018), 97, https://doi.org/10.36929/jia.v6i2.94 
Di Negara Indonesia pernikahan dini telah menjadi suatu fenomena nesional budaya yang kemudian berpengaruh besar terhadap pola kehidupan masyarakat di Indonesia. Indonesia menepati peringkat ke37 memiliki jumlah pernikahan di bawah umur dan ke-2 di Asia Tenggara. tentu hal ini bukanlah suatu kebanggaan kerena hal ini mempengaruhi kepadatan penduduk Indonesia, karena pernikahan berpotensi terhadap jumlah kelahiran yang tinggi. ${ }^{2}$

Di Jawa Timur, berdasarkan Survei Demografi dan Kesehatan Indonesia pada tahun 2017 diketahui bahwa kasus perkawinan anak, kasus kekerasan berbasis gender dan seksual, dan tingkat pengetahuan terkait hak kesehatan seksual dan reproduksi, menjadi 3 fakta yang saling berkaitan satu sama lain.

Realitas tersebut tidak mengejutkan, merujuk data dari Pengadilan Agama, yang diperoleh Dinas Pemberdayaan Perempuan, Perlindungan Anak dan Kependudukan (DP3AK) Jatim, selama pandemi COVID-19 sepanjang 2020 terjadi 9.453 kasus perkawinan anak. Pada tahun 2020, di Jember tercatat 1066 perkawinan anak usia di bawah

2 Nasution, Rosramadhana, Ketertindasan Perempuan Dalam Tradisi Kawin Anom: Subaltern Perempuan pada Suku Banjar dalam Perspektif Poskolonial, (Jakarta: Yayasan Pustaka Obor Indonesia, 2016), 1.
19 tahun yang tersebar di 31 Kecamatan dengan rincian 402 anak perempuan dan 664 anak laki-laki (Kemenag Jember, 2021). Fakta ini diperkuat dengan permohonan dispensasi perkawinan usia anak yang termuat dalam Bank Data Perkara Peradilan Agama tahun 2020, yang menyatakan bahwa Kabupaten Jember menempati ranking 2 nasional dalam jumlah usulan dispensasi perkawinan usia anak dengan jumlah 1.469 usulan dispensasi dengan 1.451 putusan usulan dikabulkan. Data ini menunjukkan tingkat keinginan masyarakat Jember menyelenggarakan dan mendaftarkan perkawinan pada usia di bawah 19 tahun sangat tinggi. (BADILAG, 2021). Permasalahan pernikahan dini sangat penting untuk kita diperhatikan, bahkan ada beberapa desa di Indonesia yang sangat merespon positif terhadap pernikahan dini ini. Karena mereka mengenggap bahwa pernikahan dini adalah merupakan tradisi dari nenek moyang mereka, maka dari itu mereks menganggap hal ini perlu dilestarikan secara turun menurun. Salah satu Desa yang masyarakatnya masih banyak melakukan pernikahan dini yaitu Desa Pace Kecamatan Silo Kabupaten Jember. Disana masih cukup banyak terjadi pernikahan di usia dini.

Oleh karena itu, penelitian ini bertujuan untuk mengetahui lebih mendalam tentang faktor penyebab serta dampak yang terjadi 


\section{Nadiratul Laeli dan Muhammad Suwignyo Prayogo}

akibat pernikahan dini, agar masyarakat dapat sadar dan mengubah pemikiran mereka yang menganggap pernikahan dini adalah suatu hal yang wajar di lakukan.

\section{Kajian Teori}

\section{Fenomena Sosial}

Fenomena sosial merupakan sebuah kejadian atau fakta sosial yang sering kita jumpai di dalam masyarakat sosial, menurut soerjono soekanto sendiri fenomena sosial merupakan masalah sosial yang berupa ketidaksesuaian antara masyarakat atau unsurunsur kebudayaan yang membahayakan suatu kelompok kehidupan sosial. Penyebab terjadinya fenomena sosial ini diakibatkan oleh perbedaan-perbedaan dalam sebuah masyarakat, baik secara kultural maupun struktural seperti agama, kebudayaan, sistem sosial dan perilaku manusia yang dapat mempengaruhi masyarakat atau suatu kelompok sosial.

Fenomena sosial juga dapat di artikan sebagai peristiwa yang sering terjadi dan kita amati dalam keseharian di kehidupan masyarakat. hakikatnya, problematika yang terjadi di masyarakat karena adanya hubungan timbal balik karena adanya proses interaksi sosial.

Fenomena sosial yang ada di kehidupan sehari-hari dapat menimbulkan masalah sosial, masalah sosial merupakan suatu gejala fenomena sosial yang mempunyai aspek kajian yang sangat luas dan dapat di definisikan dalam berbaga perspektif. Oleh karena itu kemudian ditemukan banyak definisi tentang fenomena sosial dalam masyarakat. $^{3}$

\section{Pengertian Pernikahan Dini Dan \\ Dampaknya}

Dalam masyarakat indonesia yang secara garis besar beragama islam pernikahan dini ini masih sering terjadi dan dianggap hal yang lumrah di lakukan dalam masyarakat, bahkan pernikahan dini ini menjadi persoalan dan bahan perdebatan dalam masyarakat. Kajiannya pun mencakup berbagai aspek dan melibatkan banyak pihak, seperti institusi pemerintahan, lembaga keagamaan, dan berbagai media masa (cetak, online dan televisi). ${ }^{4}$ Dalam UU No.1 Tahun 1974 tentang perkawinan, menyatakan bahwa pernikahan adalah ikatan lahir batin antara pria dengan wanita sebagai suami istri dengan tujuan membentuk keluarga yang bahagia dan kekal berdasarkan ketuhanan maha esa. Oleh karenanya sepasang suami isteri tersebut harus saling membantu dan melengkapi, agar masing-masing dari pasangan dapat mengembangkan kepribadiannya supaya sepasang suami isteri tersebut mencapai kesejahteraan baik spritual

3 Ilmawati Fahmi Imron, "Fenomena Sosial" (Banyuwangi : LPPM Agama Islam Ibrahimy Genteng, 2018, hlm 1-3

${ }^{4}$ Mayadina Rohmi Musfiroh, "Pernikahan Dini dan Upaya Perlindungan Anak di Indonesia”, Jurnal Hukum dan Syariah, Vol 8 No 2 (2016), 70, http://ejournal.uin-malang.ac.id/index.php/syariah 
maupun materii. Undang-undang ini juga menyatakan, bahwa suatu pernikahan itu sah bila dilakukan menurut hukum masingmasing agama dan kepercayaannya, setiap pernikahan harus dicatat sesuai dengan peraturan perundang-undangan yang ada.

Pengertian pernikahan dini sendiri ialah suatu bentuk ikatan atau pernikahan yang salah satu atau kedua pasangan tersebut masih berusia di bawah 18 tahun atau masih dalam pendidikan di sekolah menengah keatas. Suatu pernikahan disebut pernikahan dini, jika kedua pasangan atau salah satu pasangan masuk berusia di bawah 18 tahun. ${ }^{5}$

Dalam Syariat islam dan psikologi sosial pernikahan dini ini dibagi menjadi dua bagian, pertama pernikahan dini asli yaitu pernikahan dini yang dilaksanakan untuk menghindari dari dosa dan untuk menjauhi perbuatan zina. Kedua pernikahan dini palsu yaitu pernikahan dini yang hakikatnya dilakukan hanya untuk menutupi kesalahankesalahan yang mereka lakukan sehingga dalam hal ini orang tua juga ikut berperan. ${ }^{6}$

Undang-undang revisi Nomor 1 Tahun 1974 tentang perkawinan menyatakan bahwa pernikahan yang ideal adalah laki-laki

\footnotetext{
5 Evy Nurachma dkk, Pengaruh Pasangan Pernikahan Dini Terbadap Pola Pengasub Anak (Tanggerang: T.tp, 2018), 8

6 AbuAl-Ghifari, Pernikahan Dini : Dilema Generasi Ekestravaganza, (Bandung: Mujahid Press, 2004), 18-22.
}

berusia 19 tahun dan perempuan berusia 19 tahun, pada usia tersebut seseorang yang melakukan pernikahan sudah memasuki usia dewasa, sehingga mampu mengemban tanggung jawab dan perannya masing-masing sebagai suami maupun sebagai isteri. Namun, dalam realita yang ada dalam masyarakat masih banyak terjadi pernikahan dini, fenomena ini terjadi karena beberapa faktor penyebab dan juga memiliki dampak.

Adapun beberapa dampak dari pernikahan dini yaitu:

\section{Dampak Positif}

Hanya sedikit dampak positif yang di lakukan dari pernikahan dini yaitu agar kedua pasangan tersebut terhindar dari perilaku seks bebas dan ketika mereka menginjak usia tua kedua pasangan tersebut tidak lagi mempunyai anak yang masih kecil. Hal ini sesuai dengan yang sudah disampaikan oleh informan 3 yaitu dampak positif yang dilakukan dari pernikahan dini baik ditinjau dari segi agama yaitu agar terhindar dari terjadinya zina dan terhindar dari perilaku seks bebas, karena kebutuhan seksual mereka sudah terpenuhi, dan anggapan dari masyarakat yang sudah menjadi stigma jika menikah muda menginjak usia tua mereka tidak lagi mempunyai anak yang masih kecil. Selain hal yang sudah di uraikan di atas dampak positif yang di lakukan dari 


\section{Nadiratul Laeli dan Muhammad Suwignyo Prayogo}

pernikahan dini ialah dapat mengurangi beban orang tua karena semua kebutuhan anaknya sudah menjadi tanggung jawab suami dan harus dipenuhi oleh suami. ${ }^{7}$

\section{Dampak Negatif}

Tak sedikit dampak negatif yang di timbulkan dari pernikahan dini yaitu terputusnya pendidikan anak di karenakan pernikahan dini. terputusnya pendidikan pada anak sangat berpotensi pada rendahnya tingkat pengetahuan dan akses informasi pada anak.

Kemiskinan: kemiskinan sangat memungkinkan pada pernikahan dini ini karena kedua pasangan tersebut yang menikah dini kebanyakan masih belum memiliki penghasilan yang cukup dan bahkan masih belum bekerja. Hal inilah penyebab pernikahan di usia dini rentan dengan kemiskinan.

Kekerasan dalam rumah tangga: kekerasan pada pasangan dalam pernikahan dini ini sangat rentan terjadi karena kondisi psikis kedua pasangan yang masih labil sehingga menyebabkan emosi dan berdampak pada Kekerasan Dalam Rumah Tangga (KDRT).

Kesehatan psikologi anak: dalam pernikahan dini ibu yang mengandung di bawah umur akan menyebabkan terjadinya

7 Yanti DKK, "Analisis Faktor Penyebab dan Dampak Pernikahan Dini di Kecamatan Kandes Kabupaten Siak", Jurnal Ibu dan Anak, Vol 6 No 2 (2018), 99, https://doi.org/10.36929/jia.v6i2.94 stress, trauma berkepanjangan, kurang pengetahuan dan juga mengalami kurang kepercayaan diri.

Masalah pada anak yang dilahirkan: pada saat seorang perempuan yang masih berada pada masa pertumbuhan dan mengalami proses kehamilan, maka akan terjadi persaingan nutrisi dengan janin yang dikandungnya, hal itu akan penyebab berat badan ibu hamil sering sulit naik, dan disertai dengan anemia karena defisiensi nutrisi, serta berisiko melahirkan bayi dengan berat lahir yang rendah. Menurut penelitian sekitar 14\% bayi yang lahir dari ibu berusia remaja di bawah 17 tahun adalah bayi prematur. Anak berisiko mengalami perlakuan kurang baik atau ditelantarkan. Berbagai penelitian jyga menunjukkan bahwa seorang anak yang dilahirkan dari pernikahan usianya yang masih muda berisiko mengalami keterlambatan perkembangan, kesulitan belajar, gangguan perilaku, dan juga cenderung akan menjadi menikah di usia dini.

Kesehatan Reproduksi: kehamilan ibu saat usianya kurang dari 17 tahun meningkatkan risiko mangalami komplikasi medis, baik ibu maupun pada anak yang di kandungnya. Kehamilan di usia yang masih sangat muda ternyata juga berkorelasi dengan angka kematian dan kesakitan seorang ibu. sedangkan anak perempuan yang masih berusia 10-14 tahun berisiko lima kali lipat meninggal saat hamil maupun bersalin 
dibandingkan kelompok usia 20-24 tahun, kemudian risiko ini meningkat dua kali lipat pada kelompok usia 15-19 tahun. Hal ini disebabkan karena organ reproduksi anak belum berkembang dengan baik dan panggul juga belum siap untuk melahirkan. Data dari UNPFA tahun 2003, memperlihatkan 15\%$30 \%$ di antara persalinan di usia dini disertai dengan komplikasi kronik, yaitu obstetric fistula. Fistula adalah kerusakan pada organ kewanitaan yang menyebabkan kebocoran urin atau feses ke dalam vagina. Selain itu, juga meningkatkan risiko penyakit menular seksual dan penularan infeksi HIV $^{8}$

\section{Perkawinan Dalam Dimensi Hukum}

\section{Positif}

Dalam hukum positif perkawinan anak dilegitimasikan yaitu UU No. 1 Tahun 1974 tentang Perkawinan yang sudah direvisi, undang-undang tersebut membahas tentang pernikahan yang sah dalam hukum yang berlaku yang menyatakan bahwa usia yang ideal dalam pernikahan yaitu anak perempuan boleh menikah saat berusia 19 tahun, seperti yang tertera dalam pasal 7 ayat 1 yang sudah di revisi dan berbunyi, "Perkawinan hanya diizinkan jika pihak pria sudah mencapai 19 (Sembilan belas) tahun, dan pihak wanita

\footnotetext{
8 Mubasyaroh, "Analisis Faktor Penyebab Pernikahan Dini dan Dampaknya Bagi Pelakunya", Jurnal Pemikiran dan Penelitian Sosial Keagamaan Yudisia,

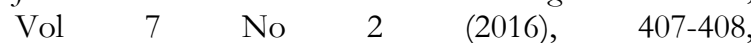
http://dx.doi.org/10.21043/yudisia.v7i2.2161
}

sudah mencapai 19 (sembilan belas) tahun." Dan pada pasal 26 UU R.I No. 23 Tahun 2002 tentang Perlindungan Anak, menyatakan bahwa orang tua wajib melindungi anaknya dari pernikahan dini. Di dalam Undang-Undang No. 35 Tahun 2004 menarasikan perubahan atas Undang-Undang No. 23 Tahun 2002 yakni mengenai Perlindungan Anak, yang dimaksudkan anak yakni seseorang yang belum 18 (delapan belas) tahun, termasuk anak yang masih berada di dalam kandungan ibunya. Anak mempunyai hak yang harus dilindungi, dijamin, dan dipenuhi oleh orang tuanya, masyarakat, keluarga, pemerintah, dan negara. Suatu hubungan pernikahan membutuhkan persiapan fisik, psikis, ekonomi, social, kecerdasan (intelektual), budaya, dan spiritual. Suatu pernikahan di usia dini tidak memenuhi syarat-syarat yang telah diatur di dalam pasal 6 yaitu kemauan bebas dari calon mempelai karena belum dewasa. Dan melakukan perkawinan dini yakni sebelum berumur 18 tahun adalah suatu pelanggaran terhadap Undang-Undang No. 35 Tahun 2014 tentang Perlindungan Anak, yang merupakan aturan yang lebih lanjut dari Pasal 28B (2) UUD 1945. Karenanya, umur 16 tahun, dalam Pasal 7 (1) UU Perkawinan telah mengakibatkan ketidakpastian hukum dan melanggar hak-hak anak yang telah 


\section{Nadiratul Laeli dan Muhammad Suwignyo Prayogo}

dijamin dalam Pasal 1 (3), Pasal 28B (2), dan juga Pasal 28C (1) UUD 1945. Agar usia 16 tahun tidak dimaknai usia menikah dalam Pasal 7 UU Perkawinan adalah secara konstitusional jika dimaknai usia 18 tahun yang beralasan menurut hukum. ${ }^{9}$

\section{Metode Penelitian}

Metode yang kami gunakan dalam penelitian ini adalah menggunakan metodelogi penelitian kualitatif, tujuannya untuk memperoleh pemahaman yang mendalam. ${ }^{10}$ Pengumpulan data melalui proses wawancara sebagai data utama sedangkan metode pelengkapnya adalah menggunakan observasi dan dokumentasi. Analisi data juga dilakukan dengan analisis data kualitatif dengan analisis deskriptif, yang bertujuan untuk menggambarkan fenomena secara sistematis dan rasional. Dan yang menjadi pusat penelitian saya adalah tentang fenomena sosial pernikahan dini di Desa Pace Kecamatan Silo Kabupaten Jember tahun 2021. Metode penyelasaian yang dilakukan untuk menangani fenomena ini adalah menggunakan metode Pendidikan Masyarakat, salah satu contohnya kami

9 Ana Latifatul Muntamah, "Pernikahan Dini di Indonesia : Faktor dan Peran Pemerintah (Perspektif Penegak dan Perlindungan Hukum Bagi Anak)", Jurnal Hukum, Vol 2 No 1 (2019), 5-7, https://doi.org/10.31328/wy.v2i1.823

10 Ismail Nurdin dan Sri Hartati, Metode Penelitian Sosial (Surabaya : Media Sahabat Cendikia, 2019), 41 mengadakan sosialisasi tentang pernikahan dini yang bertujuan untuk meningkatkan pemahaman serta kesadaran masyarakat tentang pentingnya pernikahan dan dampak dari pernikahan dini, serta beberapa solusi untuk menanggulangi pernikahan dini yang terjadi di desa Pace Kecamatan Silo Kabupaten Jember.

\section{Hasil Dan Pembahasan \\ Profil Desa Pace-Silo-Jember}

Kecamatan Silo terdiri dari dari 9 desa yang mana salah satunya adalah desa Pace. Desa Pace terletak di bagian selatan Kecamatan Silo yang memiliki luas 5.135.315 $\mathrm{ha} / \mathrm{m} 2$ yang terdiri dari 4 dusun yaitu dusun Sukmailang, Karangtenga, Curah wungkal dan Krajan serta luas wilayah ini meliputi pemukiman, perkebunan, persawahan, pekarangan, perkotaan, perkantoran, kuburan, taman dan prasana umum lainnya.

Batas-batas wilayah Desa Pace yaitu sebelah utara yaitu Desa Silo, sebelah selatan Desa Mulyorejo, sebelah barat Desa Harjomulyo dan Desa Karangharjo, dan sebelah timur yakni Hutan. mayoritas penduduk desa pace beragama Islam dan terdapat cukup beragam suku di Desa Pace Kecamatan Silo Kabupaten Jember.

Fenomena Sosial Pernikahan Dini di Desa Pace-Silo-Jember

Kehidupan masyarakat sejahtera adalah sebuah kondisi yang ideal dan di dambakan 
setiap manusia. Kesejahteraan masyarakat meliputi keamanan, keselamatan, dan kemakmukan. Karena itu masyarakat melakukan berbaga upaya untuk mengurangi atau bahkan menghilangkan faktor-faktor yang menghambat pencapaian kondisi yang ideal. Fenomena yang merupakan masalah sosial di anggap kondisi yang bisa menghambat kesejahteraan sosial. oleh karenanya masalah sosial menjadi suatu kondisi yang tidak diharapkan dan adanya masalah sosial ini selalu mendorong masyarakat atau suatu kelompok melakukan tindakan perbaikan dan perubahan. ${ }^{11}$ pada dasarnya ketika seseorang berusia kurang dari 18 tahun maka seseorang itu belum matang secara fisik, psikis maupun ekonomi. Kondisi kurang matang pada individu ini yang dimungkinkan akan menyebabkan individu menghadapai masalah setelah pernikahan. Meski demikian, pernikahan dini adalah fenomena sosial yang seriing terjadi yang menjadi salah satu permasalahan yang di hadapi ileh masyarakat pada zaman sekarang.

Tidak dapat di pungkiri masih cukup banyak beberapa desa yang beranggapan pernikahan dini sebagai perbuatan lumrah dan biasa. Desa Pace sendiri termasuk desa yang masih menganggap pernikahan dini

\footnotetext{
11 Intan Purnama Sari, "Fenomena Pernikahan di Usia Muda di kalangan Masyarakat", Skripsi, Universitas Islam Negeri Ar-Raniry (UIN) Darussalam Aceh, 2021, hlm 53
}

sebagai hal yang biasa, bahkan menurut data dari Kantor Urusan Agama kecamatan Silo tahun 2021 desa Pace menepati tingkat ke-2 paling banyak melakukan pernikahan dini. Dari hasil penelitian dan wawancara yang menyebabkan pernikahan dini masih sering kali terjadi di desa Pace adalah kurangnya pemahaman dari masyarakat mengenai pernikahan dini sehingga mereka tetap menganggap itu biasa karena dari dulu pernikahan dini sudah lumrah disana. Bagi wanita sendiri mmasyarakat Pace masih banyak memandang bahwa wanita tidak perlu berpendidikan tinggi, toh ujung-ujungnya di tetap di dapur. "sepengetahuan saya pernikahan yang terjadi di desa Pace untuk pernikahan di usia dini itu masih cukup banyak yang mengerjakannya/ melaksanakannya, meskipun pleh pihak pemerintahan tidak memperoleh hal tersebut"

Dari tingginya angka pernikahan dini di desa Pace, juga terjadi lumayan banyak perceraian di desa Pace hal ini di sebabkan remaja yang menikah muda belum siap bertanggung tawab. Sebagai akibatnya remaja mengalami berbagai hambatan seperti sulit mencari pekerjaan untuk menafkahi rumah tangganya sehingga masalah ini dapat berujung pada sikap yang keliru atau kurang 


\section{Nadiratul Laeli dan Muhammad Suwignyo Prayogo}

baik seperti kekerasan dalam rumah tangga dan stress di desa Pace kecamatan Silo.

\section{Faktor Penyebab Pernikahan Dini Di Desa Pace-Silo-Jember}

Sesuai hasil wawancara dari beberapa responden dari desa pace dapat disimpulkan bahwa terdapat beberapa faktor yang menyebabkan terjadinya pernikahan dini di Desa Pace yaitu :

\section{Faktor Ekonomi}

Ekonomi merupakan hal yang sangat penting, salah satu penyebab pernikahan di bawah umur adalah keadaan keluarga yang hidup kekurangan atau keadaan ekonomi di bawah rata-rata, maka dari itu untuk meringankan beban orang tua maka anaknya di nikahkan dengan orang yang kaya atau di anggap mampu sehingga berkurang tanggung jawab terhadap anaknya. Selain itu karena keadaan ekonomi yang rendah keluarga merasa tidak mempu membiayai anaknya sekolah sehingga anak kemudian memilih lebih cepat menikah dan orang tuanya juga merasa ketika tidak dapat melajutkan pendidikan maka lebih baik melakukan perkawinan.

Desa Peceh terletak di pegunungan, jadi mayoritas masyarkat Pace bekerja sebagai pekebun, meski di desa tetapi sawah sangat jarang di sana sehingga masyarakat memaksimalkan hasil kebun bagi yang memiliki kebun dan yang tidak memiliki biasanya mereka memperoleh dari hasil menjadi buruh yang itupun terkadang tidak setiap hari kecuali musim kopi, sehingga ekonomi masyarakat desa Pace tidak stabil dan juga lumayan banyak masyarakat di Pace memilih untuk merantau agar mereka bisa menabung membeli kebun untuk kemudian menjadi asset mereka sampai tua.

\section{Orang Tua}

Salah satu yang menjadi faktor penyebab pernikahan dini adalah karena pengaruh bahkan paksaan dari orang tua. Ada beberapa alasan orang tua di desa Pace menikahkan anaknya di umurnya yang masih muda, salah satunya karena khawatir anaknya terjerumus kepada pergaulan bebas. Hal ini juga di sebabkan di Desa Pace masih banyak orang tua yang kurang berpendidikan terutama dalam memahami pernikahan dini. Kebanyakan Orang tua di Desa Pace menganggap bahwa dengan segera menikah anak mereka akan terjauhkan dari perbuatan yang tidak di inginkan mengingat dengan berkembangnya kemajuan sangat lumrah terjadi hal yang tidak dininginkan. Beberapa orang tua di Pace juga masih memiliki tanggapan meskipun tidak sah secara resmi tapi sah secara hukum. Maka dari situ ada banyak pernikahan dini yang terjadi.

\section{Faktor Internal (Diri Sendiri)}

Selan di pengaruhi eksternal hal yang juga mempengaruhi intenal adalah dirinya sendiri, di mana ketika seorang anak remaja telah terkena asmara maka yang ada di 
pikirannya adalah keindahan cinta dan cinta, tanpa memperdulikan bagaimana besarnya tantangan yang akan di hadapi setelah pernikahan. Sehingga dengan di dukung oleh lingkungan banyak anak-anak desa Pace yang masih di bawah umur memilih untuk menikah agar mereka dapat merayakan keindahan cinta mereka dengan ikatan sakral. Selain itu karena takut menjadi pembicaraan tetangga maka dari dua belah pihak memilih untuk menikah meskipun siri agar mereka dapat mudah untuk saling bertemu tanpa memperdulikan pembicaan tetangga.

\section{Faktor lingkungan}

Lingkungan merupakan hal yang memberikan pengaruh hampir $75 \%$ bagi kehidupan manusia. Lingkungan di desa Pace sendiri masyarakatnya masih pepercayaan terhadap mitos-mitos seperti mitos bahwa wanita tidak boleh menolak jika ada orang yang melamar pertama kali karena menurut nenek moyang mereka itu perbuatan yang tidak baik, dan juga pemikiran masyarakat desa Pace mengenai perempuan tidak perlu tinggi-tinggi pendidikan karena akhirnya mereka di dapur. Serta lingkungan pace yang berada di gunung di kelilingi perkebunan, maka lebih mudah melakukan pacaran diamdiam sehingga orang tua khawatir maka kemudian orang tua memilih untuk segera menikahkan anak agar tidak terjerumus ke hal-hal buruk yang tidak diinginkan.

Solusi/strategi aparat Desa Pace-SiloJember dalam menanggulangi dan upaya pencegahan pernikahan dini

Ada beberapa strategi yang telah di laksanakan aparat Desa pace, salah satunya dengan pendekatan personal. Aparat desa Pace melakukan pendekatan personal dengan memberikan nasehat kepada masyarakat dengan secara perlahan agar mereka faham. Selain itu juga di adakan sosialisasi mengenai pernikahan dini yang salah satunya adalah permintaan bapak kepala desa kepada kami untuk mensosialisasikan pernikahan dini. Beliau berharap bahwa kita dapat merubah cara pandang masyarakat terhadap pernikahan dini. Dari sini terlihat jelas bahwa aparat desa pace benar-benar ingin meminimalisir terjadinya fenomena pernikahan dini. Sejalan dengan itu juga ada beberapa yang memicu untuk menghindari pernikahan dini yaitu di perketat aturanaturan pernikahan dini serta di buktikan beberapa dampak dari pernikahan dini seperti KDRT dll.

Dari hasil penelitian yang telah kami lakukan maka di temukan bahwa desa di desa pace masih cukup banyak terjadi pernikahn dini, hal ini disebabkan oleh adanya beberapa faktor yang mana salah satunya adalah 


\section{Nadiratul Laeli dan Muhammad Suwignyo Prayogo}

kurangnya pemahaman dari masyarakat mengenai pernikahan dini sehingga mereka tetap menganggap itu biasa karena dari dulu pernikahan dini sudah lumrah disana. jadi tidak heran jika diketahui bahwa menurut data dari Kantor Urusan Agama kecamatan Silo tahun 2021 desa Pace menepati tingkat ke-2 paling banyak melakukan pernikahan dini. Dari hal tersebut maka juga banyak berdampak kepada orang yang melakukan pernikahan salah satunya di Pace juge banyak terjadi pernikahan dini akibat kurangnya kesiapan pengantin menghadapi masalahmasalah yang timbul dirumah tangga mereka.

Berdasarkan dari hasil penelitian beberapa faktor yang menjadi penyebab terjadinya pernikahan dini di desa Pace adalah tingkat ekonomi yang masih rendah sehingga membuat orang tua tidak mempunyai pilihan selain menikahkan anaknya, Selain itu juga di sebabkan karena tingkat pengetahuan orang tua yang rendah, dan juga faktor internal yakni faktor diri sendiri dimana ketika lakilaki dan perempuan suka sama suka mereka di mabuk asmara akhirnya sepakat untuk melanjutkan kejenjang pernikahan meskipun umur mereka masih sangat muda dan juga disebabkan faktor lingkungan yang mana lingkungan desa pace masih beranggapan bahwa pernikahan dini adalah hal yang lumrah di lakukan turun temurun dari nenek moyang mereka. ${ }^{12}$

\section{Dampak Pernikahan Dini Di Desa Pace- Silo-Jember}

Beberapa dampak dari pernikahan dini di desa Pace :

a. Anak putus sekolah sehingga di desa Pace banyak anak yang putus sekolahnya karena haru fokus mengurus rumah tangga, hal ini juga mempengaruhi warga sekitar untuk tidak melanjudkan sekolah baik ke jenjang SMP, SMA atau kuliah, Akibatnyan persepsi di masyarakat bahwa perempuan tidak perlu sekolah tinggitinggi tetap hidup.

b. Banyaknya perceraian yang terjadi di karenakan terjadi beberapa problem yang tidak dapat di atasi oleh rumah tangga mereka baik itu faktor ekonomi, kekerasan rumah tangga yang di sebabkan pasangan tersebut belum sepenuhnya bisa mengontrol emosi atau bisa di sebabkan oleh faktor internal dan eksternal yang terjadi tanpa pernah mereka bayangkan sebelumnya.

\section{Simpulan}

Desa Pace kecamatan Silo Kabupaten Jember merupakan salah satu desa yang masih menganggap pernikahan dini sebagai hal yang lumrah di lakukan, beberapa faktor

12 Wawancara dengan Supriadi, Zulfia tanggal 28 Agustus di Pemukiman Desa Pace 
An-Nisa' : Jurnal Kajian Perempuan \& Keislaman

Vol. 14, No. 2, Oktober 2021

p-ISSN : $2086-0749$

e-ISSN : 2654-4784

yang menyebabkan pernikahan dini di desa Pace adalah tingkat ekonomi keluarga yang masih rendah di bawah rata-rata sehingga dikarenakan ekonomi yang rendah membuat orang tua tidak punya pilihan selain menikahkan anaknya di usia muda ditambah tingkat pengetahuan orang tua tentang pernikahan dini yang masih rendah.

Selain itu, faktor penyebab pernikahan dini adalah faktor diri sendiri, dimana karena mereka sudah saling mengenal dan mencintai akhirnya mereka sepakat untuk melanjutkan hubungan kejenjang pernikahan dan juga disebabkan faktor lingkungan yang masih menganggap pernikahan dini sebagai hal biasa. Untuk menanggulanginya aparat desa Pace melakukan beberapa upaya yang salah satunya melalui kegiatan sosialisasi.

\section{Daftar Pustaka}

Ana, Muntamah Latifatul. "Pernikahan Dini di Indonesia : Faktor dan Peran Pemerintah (Perspektif Penegak dan Perlindungan Hukum Bagi Anak)", Jurnal Hukum. Vol 2 No 1 (2019).

Al-Ghifari, Abu. Pernikahan Dini : Dilema Generasi Ekstravaganza. Bandung: Mujahid Press, 2004.

Evy, Nurachma dkk. Pengaruh Pasangan Pernikahan Dini Terbadap Pola Pengasuh Anak. Tanggerang: T.tp, 2018.
Ilmawati, Fahmi Imron. "Fenomena Sosial". Banyuwangi : LPPM Agama Islam Ibrahimy Genteng, 2018.

Intani, Purnama Sari. 'Fenomena Pernikahan di Usia Muda di kalangan Masyarakat”. Skripsi. Universitas Islam Negeri ArRaniry (UIN) Darussalam Aceh, 2021.

Ismail, Nurdin dan Hartati Sri. Metode Penelitian Sosial. Surabaya : Media Sahabat Cendikia, 2019.

Mayadina, Musfiroh Rohmi. 'Pernikahan Dini dan Upaya Perlindungan Anak di Indonesi". Jurnal Hukum dan Syariah Vol 8 No 6 (2016).

Mubasyaroh. "Analisis Faktor Penyebab Pernikahan Dini dan Dampaknya Bagi Pelakunya”. Jurnal Pemikiran dan Penelitian Sosial Keagamaan Yudisia. Vol 7 No 2 (2016).

Nasuation, Rosramadhana. Ketertindasan Perempuan Dalam Tradisi Kawin Anom: Subaltern Perempuan pada Suku Banjar dalam Perspektif Poskolonial. Jakarta: Yayasan Pustaka Obor Indonesia, 2016.

Yanti DKK. "Analisis Faktor Penyebab dan Dampak Pernikahan Dini di Kecamatan Kandes Kabupaten Siak”. Jurnal Ibu dan Anak. Vol 6 No 2 (2018). 
Nadiratul Laeli dan Muhammad Suwignyo Prayogo

184 | Pusat Studi Gender dan Anak (PSGA) LP2M IAIN Jember 